\title{
THE DIVINE APPEARANCE OF HÄRN
}

\section{Determining the identity of a Bronze Age metal hoard}

Magdalena Forsgren
This article aims to investigate the mysterious divinity Härn on the basis of a Bronze Age metal hoard from Härnevi in Uppland. The premise is that this hoard represents a cultural category that reflects a divine concept that must be investigated in order to understand the meaning behind the deposition. Through mythological parallels, Härn's characteristics will be explored as well as the relation between the sun and fertility across time and space. It is suggested that Härn originally was a sun goddess emanating from the Bronze Age and related to the Norse goddesses Njärd and Freyja.

Key words: Härnevi, metal hoard, Bronze Age, comparative mythology, folklore, sun, fertility

\section{INTRODUCTION}

How is it possible to obtain knowledge about the characteristics of an unknown divinity such as Härn who only occurs in a few Swedish place names? The name Härnevi had attracted interest for a long time (Grau I 754; Ekblom I 872), but it was not until Hans Hildebrand (I 899:6) drew attention to the sacral meaning of the second part of the place name that discussions started as to which divinity "Härn referred to; compound place names with -vi are usually theophoric. Magnus Olsen suggested in 1908 that Härn was related to one of Freyja's second names, Hørn, mentioned in Snorre's Edda. Nevertheless, it was Hans Sperber's (I9I2) suggestion that Härn is derived from an old word for 
flax which drew the greatest support. He claimed that Härn was an old demon of vegetation that subsequently merged with Freyja. Although this proposal was criticized at an early stage (Lindroth I9I 5 ), the relation between Härn and Freyja has been advocated by archaeologists, historians of religion and some onomasticians (e.g. Olsen I 9 I 5; de Vries I93 5:I 25; Hellberg I986; Näsström I 995:85; Lindeberg I997; Kraft I999; Bäck et al. 2008:8). Lars Elmevik (I995) has, however, criticized this and instead suggested that the first element of Härnevi is derived from "cerin with the meaning ársguð 'god of year's crop' which refers to Freyr. This suggestion has in turn been rejected by Per Vikstrand (200I:208) who instead claims that when tracing the origin of Härnevi it is better to assume a name with an initial $h$. His conclusion is that, although Härn probably can be understood as the name of a deity, the gender cannot be determined by linguistic means.

This article aims to determine who Härn is by using a Bronze Age metal hoard from Härnevi parish in Uppland as a point of departure, and thereby also grasp the identity of this hoard. The Härnevi hoard, containing various broken artefacts from different periods and deposited sometime before $500 \mathrm{BC}$, was discovered during ditch-digging for drainage in an arable field in I902. Originally, the idea was that Härn is one means by which to understand the deposition, but it just as likely may be the opposite. In accordance with my earlier research, the premise of this article is that the Härnevi hoard represents a cultural category that reflects a divine concept that must be investigated in order to fully understand the reasons for this deposition (Forsgren 2007,2008 ). If one understands this hoard, one may also understand the divinity Härn: what was Härn's gender, what symbols were related to this divinity, and what were its characteristics? In the following I will briefly present my current understanding of the Härnevi hoard, and then compare this understanding with mythological parallels. This work will serve as a contribution on understanding hoards as different concepts and identities as well as Bronze Age mythology.

\section{SANCTUARY OF PEACE AND PROSPERITY}

The Härnevi hoard has previously received attention in place-name discussions but most often been rejected on the assumption that metal hoards with broken artefacts should be understood in terms of scrapmetal hoards and therefore of little interest to mythological discussions (Forsgren 2008 with references; see Lundberg I9I2; Sperber I9I2; 
Vikstrand 200I:308f). An essential part of Vikstrand's discussion is therewith to point out the difficulties in determining the age of the name Härnevi due to the strong archaeological traditions back to the Bronze Age. In addition to the hoard, Härnevi parish is well known for the remains of bronze casting at a nearby settlement, and there are also several mounds of fire-cracked stones in this area (Forsgren 2007, 2008).

There are two main reasons why it is of interest to discuss the hoard and the place name together. Firstly, if one considers the place of deposition, the artefacts were discovered right in front of a triangular, inward bend in a flat, moraine plateau. The place resembles a natural, smallscale amphitheatre where it is easy to picture actors performing ritual plays (Forsgren 2008:I0). With one exception (Sahlgren I952:86), scholars have agreed that the last element of Härnevi means 'holy place' or 'sanctuary', a place which possessed a religious right of asylum and associated with peace and prosperity (Vikstrand 200I:298f, $324 \mathrm{f}$ with references). Although there are discussions on how the cult places referred to in place names were physically formed and organized in the landscape, there is a general assumption that cult places were of varying nature and often originated in the Iron Age (e.g. Vikstrand 200I; Sundqvist 2007:I43ff). It has to be stressed that no sanctuary deriving from the Iron Age has been discovered in Härnevi while at the same time it is possible to comprehend the amphitheatre as the ritual centre of a consecrated area, framed by a number of cairns at the outer edges of Härnevi (Forsgren 2008).

The second reason for discussing the hoard together with the place name is that the hoard contains many artefacts which can be considered to have had ritual functions associated with the sun, such as the hanging bowl, the domed belt ornament, and the pins with disc-shaped heads. The decorative ornaments, including double buttons, spiralinclined bracelets, a hair-spiral and one spectacle-shaped brooch, to a large extent set the standard of this hoard. Many of those artefacts can be associated with women, but the spearhead and probably also the socketed axe are normally associated with men, which makes this hoard a complex combination of artefacts and difficult to interpret. Why do weapons occur in a collection of female jewellery? Apart from ornaments and weapons, the hoard also includes serrated sickles, small pieces of leather with a button, fragments of daggers and a cauldron, and casting residue. Why are there so many different types of artefacts collected in a single hoard? (Forsgren 2007 with references). 


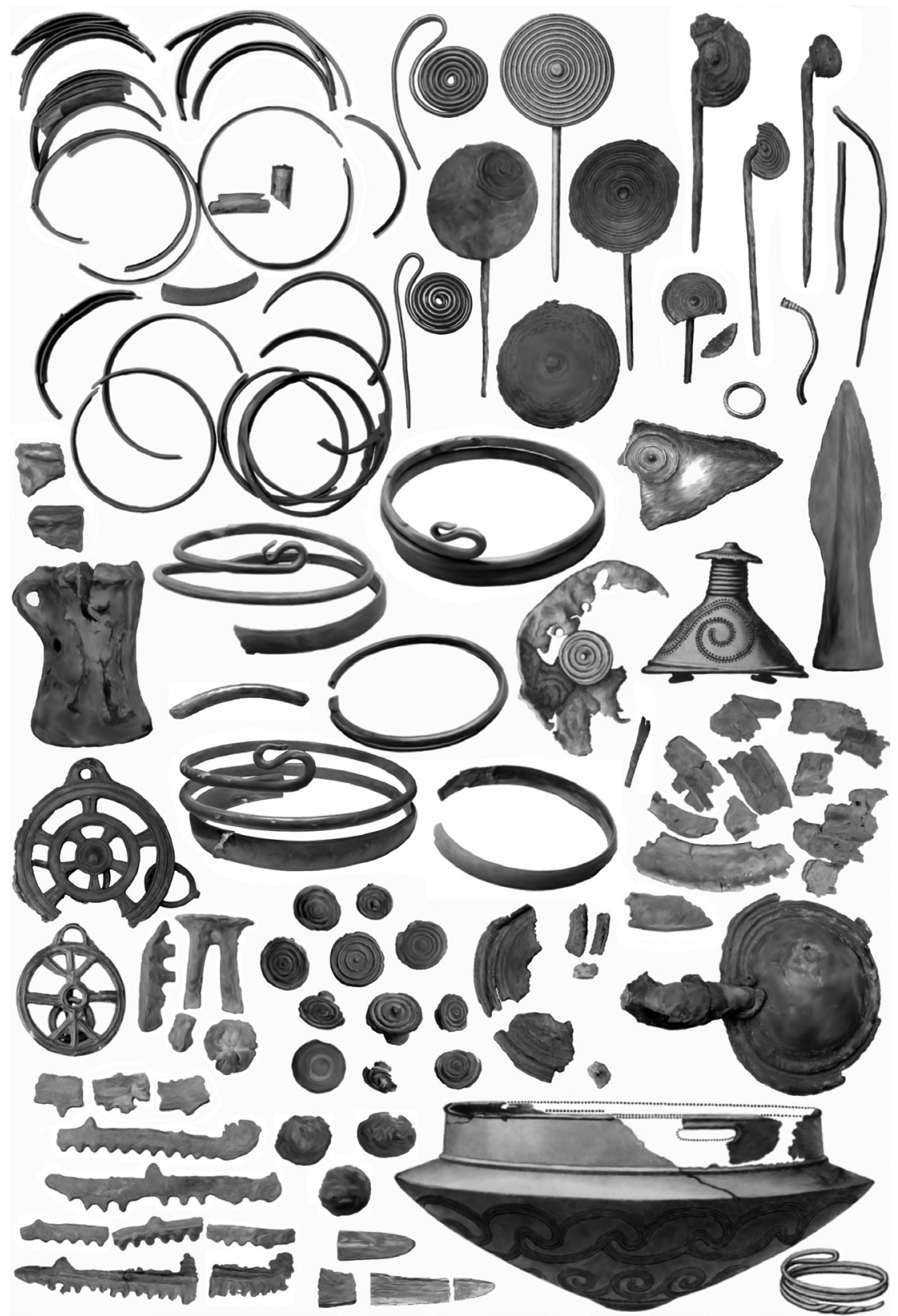

Fig. I. Collage of the Härnevi hoard. Among the female ornaments are also some tools and weapons.

Drawings by the author after Ekholm I92I and photos from the Museum of National Antiquities. 


\section{IN FAVOUR OF THE SUN}

The two wheel-like artefacts with clattering pendants are unique and have only one known parallel. The Eskelhem hoard contains, besides bridle fittings for horses and a hanging bowl, one large jingle-plate or sun-wheel which has resulted in an interpretation of this hoard as the remains of a ritual ride (Montelius I 887). Montelius recalled what Tacitus tells about the Germanic fertility goddess Nerthus: on an island in the ocean is a sacred grove where a wagon stands, used for transporting the image of the goddess through the surroundings at pax et quies 'times when all fights rested and general peace reigned'. With this as inspiration, Lundberg suggested that the artefacts in the Härnevi hoard were used when celebrating the wedding of the goddess of fertility (Lundberg I9I 2:36f; Tacitus I999 ch. 40). However, one important question arises concerning the relation between the sun and fertility.

For a long period of time researchers have agreed that Bronze Age society used the sun as a key element (e.g. Helander 1906; la Cour I924; Brøndsted 1938). However, so far not many researchers have been interested in the relation between the goddess of fertility and the sun. Yet if fertility was also of great importance during the Bronze Age, this relation ought to be further investigated. The sun seems an important element in Bronze Age religious perception, as exemplified by the famous Trundholm chariot from Denmark - a bronze wheeled model of a horse pulling a large disc with one side covered by a thin layer of gold. The chariot is also a good example of the close symbolic connection between the sun and horses during this time. Based on an analysis of mainly Late Bronze Age razors, Flemming Kaul (I998) has suggested that people in Scandinavia apprehended cosmological myths where the sun is drawn across the sky in a ship (sometimes a chariot) with the help of different animals such as horses and snakes. Snake symbolism is recurrent also in the Härnevi hoard in the form of spiral-inclined bracelets with s-shaped terminals. The terminals are similar to many handles of razors which always take the shape of animal heads. Likewise, the decoration of the bracelets from Härnevi is remindful of the pattern on a viper (Forsgren 2007:I 5 f; $c f$. Sperber's I9I 2 suggestion that bracelets can be understood as "snakes in the hands of the giantess" and used as symbolic reins).

Kaul (I998:55f) writes that "since the sun seems to have been the staple element in Bronze Age religious perception, the possibility should not be excluded entirely that the sun in one way or another can have 
developed into a personified divinity proper". If one understands how the sun was perceived in prehistoric times, one may also understand who Härn was, the combination of artefacts in the hoard, and the relation between the sun and fertility.

\section{CIRCLING THE EARTH}

What we seek is a deity associated with the sun which has horse and snake attributes and which travels across the sky in a ship or chariot. In order to continue, comparative studies must be conducted in an attempt to identify shared themes and characteristics and thereby supplement what is already known. I want to stress the importance of assuring an analytical connection in time and space when making analogies; one could therefore either compare with later Norse mythology or with Bronze Age mythologies from other areas. The first strategy gives a possible insight into pre-Christian world perception in Scandinavia, which I consider valuable to begin with because it is possible to imagine fluid traditions back to the Bronze Age. Thereby I imply that historical sources convey meanings which in certain cases may be relevant also in Bronze Age studies (Andrén 2004a).

In Norse mythology there is one solar deity to be found, namely the goddess Sól, meaning 'sun'. She and her brother Máni 'moon' were placed in the sky where Sól had to take the reins of two horses, Árvakr 'early awake' and Álsviðr 'very quick' (Grimnismál verse 37), which pull Sól's chariot Álfröðull 'elf-disc' across the sky; in Alvíssmál I 7 it is told that the elves called Sól 'the lovely wheel'. The term Álfröðull is ambiguous and not only refers to the sun-chariot but also to the sun herself. In Vafprúðnismál 23 it is told that Álfröðull will give birth to a beautiful daughter before she is eaten by the wolf Fenrir at Ragnarökr, and that this daughter will continue to ride along her mother's path (The Poetic Edda I 999). Not much else is known about Sól, perhaps because the Norse pantheon includes so many other important deities that Sól seems uninteresting in comparison. She seems, however, to have a later counterpart in Baltic mythology.

The current knowledge of Baltic, i.e. Latvian and Lithuanian, mythology is limited to a diverse and sometimes contradictory folklore material from the last centuries. Notes have nevertheless been made in earlier times in chronicles about the Balts' deification of the celestial powers, which indicate the deep traditions of the folklore material (Puhvel 1974; Biezais 1975, I987; Kokare 1996). It is worth noting 
that a sun cult seems to have existed in the Baltic countries during the Bronze Age. This is shown by the material culture which in part reflects the Scandinavian material, such as cup-marked stones, pins with discshaped heads of Härnevi-type and double buttons, which indicate cultural exchanges during this time period (e.g. Tvauri I999; Lang 2007; Luik \& Ots 2007).

\section{A NEW DAY WILL ALWAYS ARISE}

Among the gods in Baltic mythology, Saule (Lith. Saule Latv.) is a central figure. She is called màte which not only means 'mother' but also 'goddess'; Saule is thus 'the mother goddess of the sun'. Saule travels over the sky mountain from the east at dawn to the west at dusk in a chariot drawn by two white horses with golden manes. On her journey, Saule brings with her the deceased and in the evening the passengers change to a boat and travel beneath the earth. In the realm of the dead, Saule leaves the deceased so she once again can reach the east at dawn and start her journey all over again. Here a connection can be observed between chariot and boat on the one hand, and sky and water on the other. The universe can moreover be divided into two levels, heaven and earth, a division which is expressed in the word pasaule 'under the sun', meaning 'earth' (Biezais I975:33 If, I987; $c f$. Mandt I986). Of course, this is remindful of the cosmological myths illustrated by Scandinavian Bronze Age artefacts where the sun is drawn across the sky with the help of horses and snakes.

Snakes were also important in Baltic mythology, but the Balts' relation to them seems somewhat ambivalent. Occasionally snakes were enemies of Saule because they stole energy from her, and therefore they urgently had to be killed so that Saule would not start crying from fatigue. At the same time, snakes were regarded as important symbols of cyclic renewal and bearers of cosmic energy; by functioning as metaphors of the dying and reawakening nature, they shared life-giving properties of Mother Earth. Snakes also had strong sexual value and were perceived as important symbols of fertility. It was believed that snakes were able to resurrect after death and also to revive others. Thus, snakes were important in the worship of ancestors and accordingly it was regarded a sin to kill them. In some instances, Saule seems to have been friendly with snakes since they had so much in common. Possibly, although it is difficult to determine, the enmity between Saule and snakes evolved through Christian influence (Luven 200I). 


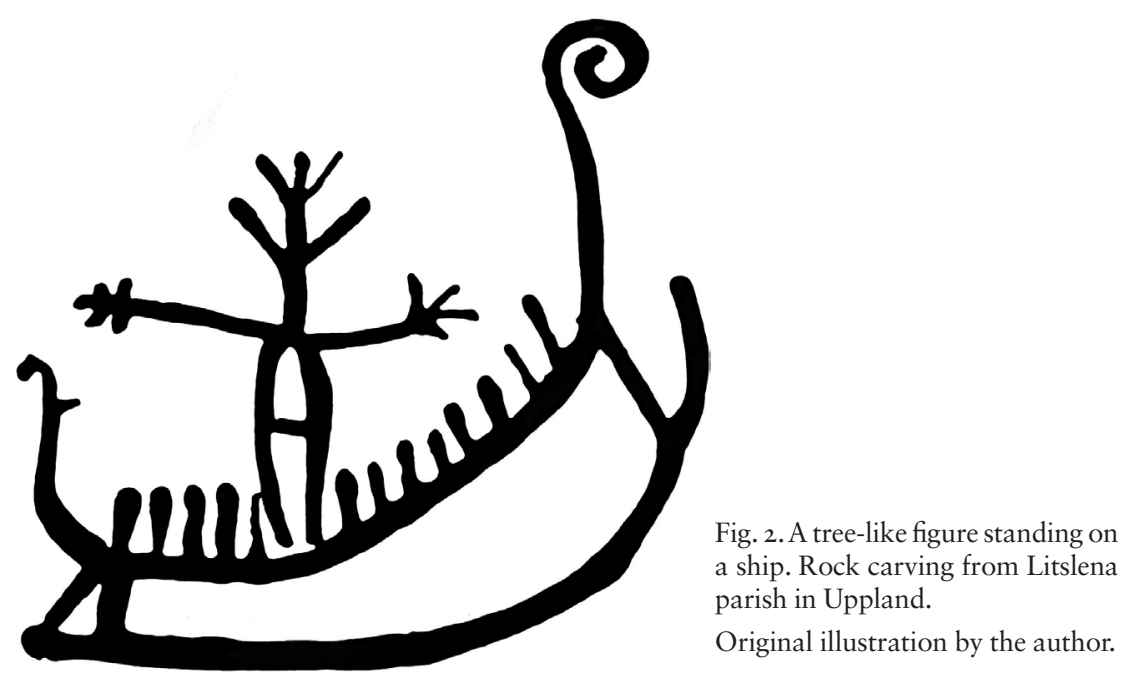

From a Scandinavian perspective, further information about Saule is of interest. Where the sun sets there grows a tree called saules koks 'the tree of the sun'. This tree was considered to be the centre of the world and the tree of life, which may go back to an old tradition where Saule was the source of life. The World Tree played an important role in Norse tradition as well, and it has been suggested that the idea of Yggdrasil as the centre of the world goes back to the Bronze Age (Andrén 2004 b). Not far from Härnevi there is a rock carving that includes a ship with a tree-like figure, which underlines this symbolism in this area during the Bronze Age. The concept of the World Tree also includes ideas about fertility. Despite Saule being a sun goddess, one of her most important roles was as goddess of growth and fertility, and the outcome of her walk across the field was a bountiful harvest (Biezais I975, I987; cf. Mandt 1986).

In order to create a structural mythological background to Saule and in extension also to Bronze Age mythology and Härnevi, some other gods in Baltic mythology should be mentioned. As in Norse mythology, the sun has a daughter which was the morning star Aušrinè (Lith; Saule Meita 'the daughter of the sun' Latv.). Even though the unreliable moon and warfare god Menulis (Lith; Mēness Latv.) was sometimes depicted as the divorced husband of Saule after the affair with Aušrine, Menulis was just as often depicted as Aušrine’'s husband. The father of Aušrinė was most probably the thunder god Perkūnas (Lith; Pērkons Latv.) which suggests that Saule and Perkūnas were once mar- 
ried. Saule sometimes also seems to have had a relationship with the god of heaven Dievas (Lith; Dievs Latv.) which is no wonder since the images of him and Perkūnas sometimes merged. The closest parallel was the Greek thunder god Zeus 'daylight' Keraunos (a paraphrase of Peraunos meaning 'thunder'; Biezais I975, I976, I987; Robbins Dexter 1984:138, 1990:40).

\section{THE ETERNAL FLAME}

One problem with the Baltic mythology is the gap in time to the Scandinavian Bronze Age. One must strive to find similar structures in Bronze Age mythologies to supplement what is known from Baltic mythology, and thereby assure the possibilities of such perceptions in regard to Bronze Age Härnevi. Such a search might provide clues as to how the occurrence of weapons in the Härnevi hoard should be understood, as well as the relation between the sun and fertility, since this is not possible by using the more recent Baltic parallel alone.

In a transcontinental perspective, there are few sun goddesses that are comparable to the Härnevi hoard and Saule. The Sun Goddess of Arinna, the highest patroness of the Hittite empire and ruler of justice, is one. To study an Anatolian goddess not only means that we move across a large geographical distance, but also that we are faced with a jumble of coalescing ancient cultures with heterogeneous and diverse pantheons. The Hittite realm corresponds in time to the earlier Bronze Age in Scandinavia (c. I800-1 I00 BC), and besides the Hittites it consisted mainly of the Luwians and Palawians. In addition, the early Hittites borrowed to a large extent their culture from the past Hattians (Haas I994a:Iff; cf. Bryce 2002:I34ff) which unlike the other peoples did not have a Proto-Indo-European background (Anthony 2007).

The importance of the Sun Goddess of Arinna can be traced back to the early time of the Hittite empire, but her origin seems much older since her predecessors probably were the Hattian sun goddesses Estan and Urunzimu 'mother earth'. For this role, chthonic properties were included as the sun travelled in the underworld during the night. Those properties were also manifested in one of the autumn festivals where the central theme was the harvesting and offering of fruits, wine and honey by the queen to the sun goddess. She was also understood as a goddess of fertility and moreover was invoked in connection with battle and with metal crafts (Haas I 994a:I90, 278, 42 Iff, 585 , cf. I $27 f f$, I 3 Iff; Bryce 2002:I 42). Here it is possible to see similarities to Härnevi; 
the hoard connects to fertility through the sickles, and at the nearby settlement traces of metal crafts have been found.

The Sun Goddess from Arinna was in her astral aspect primarily presented as a winged, golden sun-disc which also was a symbol of the Hittite kingdom, while her daughter Mezzulla was portrayed as a silver disc (Bryce 2002:I45; Haas I994a:204, 424, 426ff, 5 Iof). Possibly there was also a diffuse relationship to horses through the goddess Pirinkir, since she was also depicted as a sun-disc (Kristiansen $\&$ Larsson 2005:288; $c f$. Haas I 994a:4 I 5 f, I 994b). This of course is reminiscent of Sól's chariot Álfröðull, but it also brings to mind the two jingleplates in the Härnevi hoard.

Finally, it should be mentioned that the Hattian sun goddess Estan underwent a sex change when she was interconnected with the Hittite god Sius-summis 'our god' and became the sun god Ištanu. Sius then became a general word for 'god' in Hettite but was in origin an Indo-European word meaning 'to shine', etymologically related to the Latin deus 'god' and the Greek god of heavenly light Zeus Keraunos, the equivalent of Dievas Perkunas. The Hittite weather god Tarhun, a mythical relative to Zeus Keraunos, was portrayed as the spouse of the Sun Goddess of Arinna (Gurney I977:8ff, Iof; Haas I994a:I4I, I89, I92f, 377ff, 429; Bryce 2002:I 43f; $c f$. West 2007).

\section{THE PAN-EUROPEAN STRUCTURE}

Clearly, there are many commonalities between the Härnevi hoard and the Baltic mythology on the one hand, and the Hittite mythology on the other. At the same time, the Hittite mythology is inextricable and therefore caution is preferable before exporting the Hittite package and applying it to the Scandinavian Bronze Age. Yet it is assumed that "the sun/weather-god of heaven" Tarhun and the Sun Goddess of Arinna had counterparts in Scandinavian Bronze Age mythology that constituted separate aspects of the sun, as indicated by the day- and the night-side discs on the Trundholm chariot. This symbolism, it is argued, is consistent with several graves from the Early Bronze Age in Scandinavia in which a select group of women were buried with sundiscs of bronze (i.e. belt-plates attached to their bellies), remindful of the night-side of the chariot. Meanwhile, "a very small group of male chiefs" (Kristiansen \& Larsson 2005:294ff, 298), i.e. one, were buried with a gold disc: the day-side. Without going into details, I argue that this is not enough evidence to suggest that Scandinavian Bronze 
Age mythology included both a sun and weather god of heaven, and a night sun goddess.

In an overview of Indo-European religions and languages, it is noted that the sun was broadly viewed as masculine. This does not apply to northern Europe where a zone with different sun goddesses appears, perhaps influenced by substrate populations (West 2007:I95f). The sun was regarded as female in Sámi mythology as well, and perceived as a life-giving mother. A sun girl and a thunder god can also be noted (Mebius 2003:75ff), which is comparable to Baltic mythology. Axel Olrik (1905) assuredly believed that several elements of the Sámi mythology suggested influences from the Scandinavian Bronze Age. He assumed, however, that the sun was masculine in the latter, and consequently the Sámi sun must have later undergone a sex change and become female. For reasons of Swedish sovereignty this interpretation is perhaps not surprising, but it must be contradicted. The sun was most likely female in origin (Mebius 2007:56f) and had similarities with Saule and a Bronze Age female counterpart.

When trying to understand Scandinavian Bronze Age mythology, perhaps it is better to look to neighbouring mythologies before drawing advanced conclusions on the basis of parallels with remote societies (e.g. Kristiansen \& Larsson 2005). Comparisons between Bronze Age Scandinavia and various Mediterranean cultures seem to cause difficulties. Previously there have been heated discussions on whether or not there were transfers of diverse cultural expressions from the eastern Mediterranean to Scandinavia. For example, a discussion about similarities between the Scandinavian symbolism and that of the Minoan culture gives indications of long-range contacts and exchange of ideas between remote societies at an elite level, thus serving as an explanation for the cultural life in Bronze Age Scandinavia. The main reason for the recent outward-looking approach is that the Bronze Age research of the last decades has been conducted from an autonomous perspective where essential parts of the past have been overlooked since research often has been limited by present-day national borders and language differences (e.g. Sherrat I994; Kristiansen I998; Larsson I999; Malmer I999; Randsborg 1999; Winter 2001; Fari 2006; Kaul 2009).

Critics for their part have claimed that such neo-diffusionist projects are flirting with Europeanism, which is not academically relevant since one cannot acquire nuanced knowledge by drawing parallels with today's global situation and asserting there was something re- 
sembling a European community during the Bronze Age (e.g. Gröhn 2004; Sjögren 2006; Nordquist 2008). However, the main purpose of recent discussions is to open up new possibilities to understand dimensions of the Bronze Age society which otherwise would be considered unreachable and therefore academically less relevant to study. This is desirable although the methods used can be discussed (Winter 2008). In the Mediterranean alone, a series of problems occur when trying to find "similarities from quite different geographical, cultural and temporal contexts" in such cases where transfers are suggested (Sjögren 2006; cf. Nordquist \& Whittaker 2007). Indeed, it can be regarded as a problem when various Mediterranean cultures are brought together in one ideological package and carried to Scandinavia where carefully selected artefacts illustrate a pan-European structure without the different cultural contexts being taken into account.

\section{OH MOTHER EARTH, THOU GRACIOUS}

Notwithstanding this, there were connections between various complex deities in the Mediterranean (cf. Marinatos 2000). At the end of the Hittite empire, a synchronization process was implemented and similar deities were grouped together and treated as equal. The Sun Goddess of Arinna was thus identified with the mother goddess Hepat, the mother of all living, although Hepat never had any solar aspects. Hepat is often depicted standing on a lion, as is also the Babylonian and Assyrian goddess Ištar, the goddess of physical love, procreation, and war. The Hittite king Hattušili III made Ištar his favourite goddess, which may seem somewhat strange since he, who was "beloved of the Sun Goddess of Arinna", married the Hurrian priestess Puduhepa 'servant of Hepat', the daughter of a priest of Ištar. In one of her prayers Puduhepa says: "In the Land of Hatti you bear the name of the Sun Goddess of Arinna; but in the land which you made the cedar land you bear the name Hepat" (Bryce 2002:287; Haas I994a:638). A later counterpart was most probably the Phrygian goddess Cybele, the fertile earth, who came to be worshiped throughout large parts of Europe for over a millennium (Burkert I979:IO2ff).

Apart from not being sun deities, none of these fertility goddesses had any links to snakes or horses. Recent attempts have been made, however, to connect the Sun Goddess of Arinna to Athena, the goddess of wisdom and justice whose main concerns were war and the protection of people. She appears in classical Greek mythology as an armed 
warrior often attended by an owl and a snake. She was the guardian of metal craft and had a strong association to weaving and the cultivation of olive trees, but to some extent she was also connected with water, ships, horses and wagons (Teffeteller 200I; cf. Luyster I965; Burkert I979:220ff; Marinatos 2000). Many of these phenomena are also known from Härnevi and the Scandinavian Bronze Age mythology. Besides the bracelets and the jingle-plates, the Härnevi hoard also includes a spearhead and an axe. As mentioned earlier, apart from the hoard Härnevi is also well known for bronze casting and therefore it is possible that the divine concept illustrated by the hoard was a guardian of metal craft. As a fruitful olive tree, Athena's tree also bears some resemblance to Saulè's life-giving tree and to Yggdrasil. However, if the Sun Goddess of Arinna can be considered as a precursor to Athena, then Athena being a daughter and not a wife to Zeus Keraunos must be seen as a later addition (Neils 200I; Tefeteller 200I).

One can wonder how far parallels may be drawn without arguments losing in strength. For the time being, I agree with Kaul (I998:26I) that "the best approach is to accept our iconography on its own terms, using foreign parallels as illustrations but not as arguments"; this is easier said than done, however. Given that fertility goddesses seem to have been of great importance in many cultures around the eastern Mediterranean, it may again be appropriate to draw attention to Tacitus' Nerthus, the Germanic Iron Age mother goddess. It has previously been suggested that Nerthus could be a counterpart of Cybele ( $c f$. Näsström I995:23 ff). As it is possible to observe a greater female presence during the Bronze Age with an increased frequency of jewellery and female bronze figurines, Nerthus has several times come to be mentioned as a goddess of fertility introduced during the Late Bronze Age. Such an assumption also seems to have been necessary since previously it has been taken for granted that the sun was masculine and not feminine (e.g. Montelius I900; Helander 1906; Arne 1909; Bjørn I 924:7ff; Almgren I927; Davidson I969; Görman I989; Kaul 2009).

\section{THE ALL-POWERFUL GODDESS}

When studying Norse mythology, it is possible to see connections between different gods assembled in holy units. This may be consistent in the spatial distribution pattern of deities in place names. "Njärd, which is the Scandinavian variant of Nerthus, constitutes most often the female part of those holy couples, but in the north-east Mälaren 
region she is replaced by Härn (Olsen I9I 5; Wessén I923). Njärd has in turn been associated with Freyja since the father of Freyja and Freyr was Njorðr, one of the Vanir who were a distinguished group of divinities in Norse mythology foremost associated with fertility. Closely connected to the Vanir was the expression til árs ok friðar 'for a good year's crop and peace', which is equivalent to Tacitus' expression pax et quies. Both Freyr and Freyja seem to have been the main divinities of fertility. It has been suggested that their names from the beginning functioned as titles meaning 'lord' and 'lady' and that Njorðr and Njärd were the real names of this divine couple. Consequently they were named Njorðr freyr and Njärd freyja (Kock I 896). In Sweden Njorðr is often exchanged with Ullr in the place-name material, and possibly Freyr and Ullr were one and the same god, Ullr freyr (Grimnismál $5 \mathrm{I}$ ). In The Poetic Edda, Ullr is depicted as the stepson of the thunder god Thor and thus has a somewhat similar position as the Baltic moon god Menulis who is the son-in-law of Dievas Perkūnas. Interestingly enough, the nearest theophoric place name to Härnevi is Torslunda in Torstuna parish to the north, and this spatial relation between Thor and Härn is of utmost interest with regard to what is known from other mythologies. I want to stress the possibility that the Bronze Age mythology included other celestial deities than only the sun, even though the sun probably was at the centre of much religious worship.

Interesting but definitely not unproblematic relationships between various deities do not seem to stop here. A tenable connection between the goddesses Freyja and Frigg can be noted. Through Snorre, we know that Frigg is the first among Ásynjur, but that Freyja is tígnuz með 'the most prominent together with' Frigg. Sometimes Freyja is even ágæetust of ásynjum 'the most excellent of the goddesses' (Näsström I995:I04f). An attempt to problematize this connection has been made (Grundy I996), but if other materials are considered as well, and if descriptions of Frigg and Freyja are compared, there emerges an indication of a common origin (Näsström I995:I06ff). Simply the fact that both are married to Óðinn and Oðr, respectively, results in this possibility. This cannot be easily ignored because there is not much doubt that the husbands, too, were originally the same god (Näsström I995:8 If, II3).

Tales about Óðinn chasing a female being with flowing hair and sagging breasts through forests and across the sky can be found in folklore material. In Swedish folklore she is named Skogsrået 'lady ruler of the 
forest' and Huldra 'the hidden one' in Norwegian (Granberg 1935). The name Huldra resembles Hulðr Seiðkonu in Heimskringla and Frau Hulda in German folklore, of which the latter has been connected with Freyja. Freyja, for her part, is the goddess of seið and she taught this practice to Frigg and Óðinn (Näsström I995:8 2f, 2 Ioff). Possibly, Skogsrået can in some tales be considered a successor to Freyja.

The traditions of Skogsrået were examined by Gunnar Granberg in his doctoral dissertation from I 935 . However, one tradition of interest in the context of this paper has not been recorded. This tale comes from the southern part of Torstuna parish nearby Härnevi and partly reflects some of the concepts discussed above. "Då en ä ute å går i skogen, ska en noga aktas för te jöra illa skogsrån för on uppenbarer se på många olika vis. Iblann visar hon se som en orm, iblann som en ormila, iblann som en groda. För jägare visar hon se iblann som en vacker flicka, men ryggin är urholka som en svinho. Dömmerså får en lov te vara försiktin me ormar å ormilor" "When someone is out in the forest, they should be careful not to upset Skogsraiet, because she appears in many different ways. Sometimes she appears as a snake, sometimes as a slow-worm, and sometimes as a frog. To hunters, she sometimes appears as a beautiful girl, but her back is hollow as a pig's trough. Judge thereafter: one must be careful with snakes and slow-worms" (Bladh et al. 1979:353, my translation). In addition to the link between Skogsrået and snakes, it was typical of frogs in old traditions to be regarded as symbols of fertility and childbirth (Lövenkrona I989).

\section{TRAVELLING BACK AND FORTH}

For me it is not impossible to picture the Härnevi hoard as the material remains of a ceremony representing the sun's journey across the sky. If one considers the association to fertility, this hoard could also be interpreted as a metaphor for the cycle of life which was part of an ideology in which the seasonal coming, disappearing and recurring were expressed through conceptions regarding agriculture (Forsgren 2008:22; cf. Thedéen 2003). When taking the artefacts and their symbolic associations into consideration, an image of a sun goddess with roots in the Bronze Age emerges. Since this divine concept appears in a place called Härnevi, I argue that Härn was the name of this goddess in Uppland. It is indeed possible that the artefacts in the Härnevi hoard were used by someone who assumed the identity of a goddess, and in that case it is also possible to discern ritual activities in Härnevi, which 
is suitable since the last element of the place name refers to a sanctuary of peace and prosperity (Forsgren 2007, 2008).

Several of the artefacts in the hoard have their symbolic counterparts elsewhere and suggest that Härn as well as her parallels was complex in character. Spears, daggers and axes are evocative of war, while sickles are rather reminiscent of crops. Thus, this hoard was a tangible manifestation of the expression til árs ok friðar (Forsgren 2008:22f). Härn would thus have been a goddess who was associated with both war and peace in a similar manner as the Sun Goddess of Arinna, Athena and Nerthus. That these goddesses along with Saule had links to the World Tree further underlines their role as fertility goddesses ( $c f$. Freyja's fruit tree, Näsström I995:2 I3). Through comparative parallels it is also possible to see strong links to a god of thunder, which is interesting since the nearest parish to Härnevi is Torstuna.

One of the key problems in my paper is to try to understand the relation between the sun and fertility. In particular, two types of objects indicate that Härn can probably be considered a sun goddess in a cosmic myth, namely the spiral-inclined bracelets with s-shaped terminals and snake pattern, and the jingle-plates which refer to both horses and the sun. This symbolism is also found in the Bronze Age cosmological myths that people during this period most likely apprehended (Kaul I998). In the Mediterranean, however, it is easily noted that fertility aspects dominated regarding the great goddess while at the same time the sun was perceived as masculine. Yet this does not apply to north-west Europe where the sun instead was perceived as feminine (West 2007).

A tentative hypothesis can be put forth which possibly also can explain the relation between Härn and Njärd Freyja. An assumption can be made that the various fertility goddesses around the Mediterranean were variants of each other and that at least one of them inspired the concepts of the Germanic goddess Nerthus and a former Celtic counterpart (cf. Görman I989). A further assumption is that during the end of the Stone Age or Early Bronze Age a new mythology was slowly introduced into southern Scandinavia and the Baltic, influenced by Indo-European cultures, but a sun goddess common to all people of northern Europe was continuously being worshiped (cf. Mandt I986). During the course of the Bronze Age more and more influences from the Celtic world can be noticed, but the belief in the sun goddess continued. In the transition to the Celtic Iron Age, the focus switched for some reason to the worship of a more specialized fertility goddess who 
came to be referred to as Njärd Freyja. This hypothesis requires future research, but nevertheless it should be noted that Freyja, too, had links to the sun which is underlined by the following verse:

"Seij nu Torkar svar igen, han skal aldrig hammarn få, för ähn jag fåhr Jungfru Froijenborg, den vähna solen tå”

"Trolltram sänder dig svahr igen, du kan eij hammaren få, för ähn han fåhr Jungfru Froijenborg, den vähna solen tå”

"Answer Thor once again, that he never will receive the hammer until I have the maid Freyja, the fair sun then."

"Trymer is sending you an answer again, you cannot receive the hammer until he gets the maid Freyja, the fair sun then."

(from the Swedish song Hammar-Hemtningen. Arwidsson I 834, my translation)

\section{Acknowledgment}

I wish to thank Christina Karlsson, University of Southampton, for encouragement, and Martin Hansson and Laura Wrang for the great help to achieve the final result. Many thanks as well to Ingmar Jansson for having been a wonderful supervisor during the writing of my seminar papers. Anna Källén is recognized for having read a later version during Thesis II. 


\section{References}

Andrén, A. 2004a. Mission Impossible? The Archaeology of Norse Religion. In: Insoll, T. (Ed). Belief in the Past. BAR International Series I 2 I 2. Pp. 7-I6. Oxford: Archaeopress.

- 2004b. I skuggan av Yggdrasil. Trädet mellan idé och realitet i nordisk tradition. In: Andrén, A., Jennbert, K. \& Raudvere, C. (Eds.). Ordning mot kaos. Studier av nordisk förkristen kosmologi. Vägar till Midgård 4. Pp. 389-430. Lund: Nordic Academic Press.

Anthony, D. W. 2007. The Horse, the Wheel, and Language. How the Bronze-Age Riders from the Eurasian Steppes Shaped the Modern World. Princeton: Princ. Univ. Press.

Almgren, O. I927. Hällristningar och kultbruk. Bidrag till belysning av de nordiska bronsåldersristningarnas innebörd. KVHAA handlingar 35. Stockholm: Wahlström \& Widstrand.

Arne, T. J. I909. Några i Sverige funna bronsstatyetter af barbarisk tillverkning. Fornvännen. Vol. 4. Pp. I75-I 87.

Arwidsson, A. I. I834. Svenska fornsånger. En samling af kämpavisor, folk-visor, lekar och dansar samt barn- och vall-sanger. Stockholm: Norstedt.

Biezais, H. I975. Baltische religion. In: Ström, Å. \& Biezais, H. (Eds). Germanische und Baltische Religion. Die Religionen der Menschheit I9: I. Stuttgart: Kohlhammer.

- I976. Lichtgott der alten Letten. Scripta Instituti Donneriani Aboensis 8. Stockholm: Almqvist \& Wiksell International.

- I987. Baltic religion. The Encyclopedia of Religion. Vol. 2. Eliade, M. (Ed). Pp. 49-55. New York: Macmillan.

Bjørn, A. 1924. Gudinden med halsringen. Ett fragment. In: Haug og Museum. Til A.W. Brøgger, 40 Aars-Dagen. Pp. 7-I3. Kristiania [Oslo]: Universitetets Oldsamling.

Bladh, A. et al. I979. Tre sockenkrönikor. Härnevi, Torstuna, Österunda. Enköping: Härnevi hembygdsförening.

Bryce, T. 2002. Life and Society in the Hittite World. Oxford: Oxf. Univ. Press.

Brøndsted, J. 1938. Bronzealderens soldyrkelse. Copenhagen: repr.

Burkert, W. I979. Structure and History in Greek Mythology and Ritual. Berkeley: Univ. of Calif. Press.

Bäck, M., Hållans Stenholm, A-M., Ljung, J-Å. 2008. Lilla Ullevi- historien om det fridlysta rummet. UV Mitt. Hägersten: Riksantikvarieämbetet.

la Cour, V. 1924. Solens personifikation i vor Broncealder. Danske Studier I924. Pp. I2I-I34.

Davidson, H. R. E. 1969. The Chariot of the Sun. Folklore. Vol. 80. Pp. I74-I80.

Ekblom, J. E. I 872. Beskrifning öfver Hernevi socken. Enköping: C.E. Eriksson.

Ekholm, G. I92 I. Studier i Upplands bebyggelsehistoria. Bronsålder. Uppsala: Akad. bokh.

Elmevik, L. 1995. Härnevi och Friggeåker. Namn och bygd. Vol. 83. Pp. 67-77.

Fari, C. H. 2006. Hieros-gamos. En sammenligning mellom symbolets uttrykk i den nordiske bronsealderens helleristningstradisjon og myteverdenenn i det østlige middelhavsområdet. In: Prescott, C. (Ed). Myter og religion ibronsealderen. Oslo archaeological series 5. Oslo: Institutt for ark., kunsthist. og konserv. 
Forsgren, M. 2007. Depåfyndet från Härnevi, del I. Föremålsförståelse och genusperspektiv med utgångspunkt frän ett s.k. skrotfynd frän yngre bronsailder $i$ Uppland. BA thesis in archaeology. Stockholm University.

- 2008. Depåfyndet från Härnevi, del II. Sammanhang och förståelse av en fragmenterad bronsdepå i torrmark frain yngre bronsailder i Uppland. MA thesis in archaeology. Stockholm University.

Granberg, G. 1935. Skogsrået i yngre nordisk folktradition. Skrifter utg. av Kungl. Gustav Adolfs akademien för folklivsforskning 3 . Uppsala: Lundequistska bokh.

Grau, O. I754. Beskrifning öfwer Wästmanland med sina städer, härader och socknar. Västerås.

Grundy, S. 1996. Freyja and Frigg. In: Billington, S. \& Green, M. The Concept of the Goddess. Pp. 56-67. London \& New York: Routledge.

Gröhn, A. 2004. Positioning the Bronze Age in Social Theory and Research Context. Acta Archaeologica Lundensia. Series in $8^{\circ}$ 47. Stockholm: Almqvist \& Wiksell.

Gurney, O. R. 1977. Some Aspects of Hittite Religion. Oxford: Publ. for The British Academy by Oxf. Univ. Press.

Görman, M. 1989. Nordiskt och keltiskt. Sydskandinavisk religion under yngre bronsålder och keltisk järnålder. Lund: cop.

Haas, V. I994a. Geschichte der hethitischen Religion. Leiden: E. J. Brill.

- I994b. Das Pferd in der hethitischen religiösen Überlieferung. In: Hänsel, B. \& Zimmer, S. (Eds). Die Indogermanen und das Pferd. Pp. 77-90. Budapest: Archaeolingua Alapítvány.

Helander, J. I906. Den svenske solguden och den svenske Tyr. Ord och bild. Pp. I76-I94.

Hellberg, L. I986. Hedendomens spår i Uppländska ortnamn. Ortnamnssällskapets i Uppsala årsskrift I986. Pp. 40-7I.

Hildebrand, H. I899. Sveriges medeltid 3. Stockholm: Gidlund.

Kaul, F. 1998. Ships on Bronzes. A Study in Bronze Age Religion and Iconography. Copenhagen: National Museum.

- 2009. En solguds mange skikkelser. En mystisk kosmologisk rejse. In: Nationalmuseets Arbejdsmark 2009. Copenhagen: National Museum.

Kock, A. I896. Die Göttin Nerthus und der Gott Njorðr. Zeitschrift für Deutsche Philologie. Vol. 28. Pp. 289-294.

Kokare, E. 1996. A Survey of the Basic Structures in Latvian Mythology. Journal of the Baltic Institute of Folklore. Vol. I. http://www.folklore.ee/rl/pubte/ee/ bif/bifı/sisu.html.

Kraft, J. I999. Hednagudar och hövdingadömen i det gamla Skandinavien. Upplands-Bro: cop.

Kristiansen, K. 1998. Europe Before History. Cambridge: Camb. Univ. Press.

Kristiansen, K. \& Larsson, T. B. 2005 . The Rise of Bronze Age Society. Travels, Transmissions and Transformations. Cambridge: Camb. Univ. Press.

Larsson, T. B. I999. The Transmission of an Elite Ideology. Europe and the Near East in the Second Millennium BC. In: Goldhahn, J. (Ed). Rock Art as Social Representation. BAR International Series 794. Pp. 49-64. Oxford: Archaeopress.

Lang, V. 2007. The Bronze Age and Early Iron Age in Estonia. Tartu: Tartu Univ. Press.

Lindeberg, M. 1997. Gold, Gods and Women. Current Swedish Archaeology. Vol. 5. Pp. 99-i Iо. 
Lindroth, H. I9I 5 . Härnevi. Ett bidrag till frågan om beröringen mellan svensk och finsk mytologi. Namn och bygd. Vol. 3. Pp. 57-9I.

Luik, H. \& Ots, M. 2007. Bronze Age Double Buttons in Estonia. Estonian Journal of Archaeology. Vol. I I. Pp. I22-I 40.

Lundberg, O. I9I2. Härnevi och därmed sammanhängande ortnamn. Om nordisk fruktbarhetskult. In: Lundberg, O. \& Sperber, H. (Eds). Härnevi. Pp. 3-40. Uppsala: Uppsala univ. årsskrift.

Luven, Y. 200I. Der Kult der Hausschlange. Eine Studie zur Religionsgeschichte der Letten und Litauen. Quellen und Studien zur baltischen Geschichte I7. Köln: Böhlau.

Luyster, R. I965. Symbolic Elements in the Cult of Athena. History of Religions. Vol. 5. Pp.I33-I63.

Lövenkrona, I. 1989. The Pregnant Frog and the Farmer's Wife. Childbirth in the Middle Ages as Shown Through a Legend. ARV. Scandinavian yearbook offolklore I989. Pp. 73-I24. Stockholm: Gustav Adolfs akademien.

Malmer, M. I999. How and Why did Greece Communicate with Scandinavia in the Bronze Age? In: Orrling, C. (Ed). Communication in Bronze Age Europe. Pp. 33-42. Stockholm: Historiska museet.

Mandt, G. 1986. Searching for Female Deities in the Religious Manifestations of the Scandinavian Bronze Age. In: Steinsland, G. (Ed). Words and Objects. Towards a Dialogue between Archaeology and History of Religion. Pp. I I I-I 26. Oslo: Norw. Univ. Press.

Marinatos, N. 2000. The Goddess and the Warrior. The Naked Goddess and Mistress of Animals in Early Greek Religion. London: Routledge.

Mebius, H. 2003. Bissie. Studier i samisk religionshistoria. Östersund: Jengel.

Montelius, O. I 887. Ett fynd från Eskelhems Prestgård på Gotland. KVHAA Månadsblad. Vol. I6. Pp. I45-I79.

- I900. Solgudens yxa och Tors hammare. Svenska fornminnesföreningens tidskrift. Vol. ro. Pp. 277-296.

Neils, J. 200 I. Athena, Alter Ego of Zeus. In: Deacy, S. \& Villing, A. (Eds). Athena in the Classical World. Pp. 219-232. Leiden: Brill.

Nordquist, G. 2008. Perspectives on the "Bronze Age". In: Whittaker, H. (Ed). The Aegean Bronze Age in Relation to the Wider European Context. BAR International Series I745. Pp. 95-I03. Oxford: Archaeopress.

Nordqust, G. \& Whittaker,H. 2007. Comments on Kristian Kristiansen and Thomas B. Larsson (2005): The Rise of Bronze Age Society. Travels, Transmissions and Transformations, Cambridge. Norwegian Archaeological Review. Vol. 40. Pp. $75^{-84}$.

Näsström, B-M. I995. Freyja. The Great Goddess of the North. Lund studies in history of religion 5. Stockholm. Almqvist \& Wiksell.

Olsen, M. 1908. Hoernavi. En gammel svensk og norsk gudinde. Christiania videnskabs-selskabs forhandlingar for I908, 6. Christiania [Oslo]: Kulturorgan Skadinaujo.

- I9I 5. Hedenske kultminder i norske stedsnavne. Christiania [Oslo]: J. Dybwad i kommission.

Olrik, A. 1905. Nordisk og lappisk gudsdyrkelse. Bemerkninger i anledning af solvognen fra Trundholm. Danske studier I905. Pp. 39-57.

Puhvel, J. 1974. Indo-European Structure of the Baltic Pantheon. In: Larson, G. J. (Ed). Myth in Indo-European Antiquity. Pp. 75-8 5 . Berkeley: Univ. of Cal. Press. 
Randsborg, K. I999. Kivik Power of Communication. In: Orrling, C. (Ed). Communication in Bronze Age Europe. Pp. 22-32. Stockholm: Historiska museet.

Robbins Dexter, M. 1984. Proto-Indo-European Sun Maidens and Gods of the Moon. Mankind Quarterly. Vol. 25. Pp. I37-I 44.

- I990. Whence the Goddesses. A Source Book. New York: Pergamon Press.

Sahlgren, J. I952. Härads- och sockennamnen. Sveriges bebyggelse. Statistik-topografisk beskrivning över Sveriges städer och landsbygd. Landsbygden. Uddevalla: Hermes.

Sherrat, A. 1994. What Would a Bronze Age World System Look Like? Journal of European Archaeology. Vol. I. Pp. I-58.

Sjögren, J. 2006. Minoan Wannabees. The Resurrection of Minoan Influences in Scandinavian Archaeology. Momigliano, N. \& Hamilakis, Y. (Eds). Archaeology and European modernity. Producing and consuming the 'Minoans'. Creta antica 7. Pp. I27-I42. Padova: Bottega d'Erasmo.

Sperber, H. I9I 2. Härnevi. Vermutungen über die Etymologie von aschw. Hærn, aisl. Hørn. N: Lundberg O. \& Sperber, H. Härnevi. Pp. 4 I-49. Uppsala: Upps. Univ. årsskrift.

Sturluson, S. I9I6. The Prose Edda. Gilchrist Brodeur, A. (transl.). New York: The American-Scandinavian Foundation.

Sundqvist, O. 2007. Kultledare ifornskandinavisk religion. OPIA 4I. Uppsala: Upps. Univ.

Tacitus, C. 1999 [ca 98 AD]. Germania. De Origine et situ Germanorum (orig.). Rives, J. B. (transl.). I999. Oxford: Clarendon.

Taffeteller, A. 200 I. Greek Athena and the Hittite Sungoddess of Arinna. In: Deacy, S. \& Villing, A. (Eds). Athena in the Classical World. Pp. 349-365. Leiden: Brill.

Thedéen, S. 2003. Life Course Practices in Bronze Age Landscapes of East Central Sweden. Beyond Devine Chiefs and Neodiffusionism. Current Swedish Archaeology. Vol. I I. Pp. 97-I I 8.

The Poetic Edda. 1999. Larrington, C. (transl.). Oxford: Oxf. Univ. Press.

Tvauri, A. 1999. Cup-marked Stones in Estonia. Electronic Journal of Folklore. Vol. I I. http://www.folklore.ee/Folklore/ksisu.htm

Vikstrand, P. 200I. Gudarnas platser. Förkristna sakrala ortnamn i mälarlandskapen. Acta Academiae Regiae Gustavi Adolph 77. Studier till en svensk ortnamnsatlas I7. Uppsala: Kungl. Gustav Adolfs akademien för svensk folkkultur.

de Vries, J. I935. Altgermanische Religionsgeschichte, Bd I. Einleitung, Die vorgeschichtliche Zeit, Religion der Südgermanen. Grundriss der germanischen Philologie I2:I. Berlin: Gruyter.

West, M. L. 2007. Indo-European Poetry and Myth. Oxford: Oxf. Univ. Press.

Wessén, E. I 923. Minnen av forntida gudsdyrkan i Mellan-Sveriges ortnamn. Studier inordisk filologi. Vol. I4. Pp. I-26.

Winter, L. 200I. Cultural Encounters. Symbols from the Mediterranean World in the South Scandinavian Rock Carving Tradition During the Bronze Age. In: Werbart, B. (Ed). Cultural Interactions in Europe and the eastern Mediterranean during the Bronze Age (3000-500 BC). BAR International Series 985. Pp. 9-28. Oxford: Archaeopress.

- 2008. From Diffusion to Interaction. Connections Between the Nordic Area and Valcamonica During the First Millennium BC. In: Whittaker, H. (Ed). The Aegean Bronze Age in Relation to the Wider European Context. BAR International Series I745. Pp. 35-55. Oxford: Archaeopress. 